\title{
Potential for a localized immune response by the ruminal epithelium in nonpregnant heifers following a short-term subacute ruminal acidosis challenge
}

\author{
C. Kent-Dennis, ${ }^{1}$ A. Pasternak, ${ }^{2}$ J. C. Plaizier ${ }^{3}$ and G. B. Penner ${ }^{1, *}$ \\ ${ }^{1}$ Department of Animal and Poultry Science, University of Saskatchewan, Saskatoon, SK S7N 5A8, Canada \\ ${ }^{2}$ Department of Large Animal Clinical Sciences, Western College of Veterinary Medicine, University of Saskatchewan, Saskatoon, SK S7N 5A8, \\ Canada \\ ${ }^{3}$ Department of Animal Science, University of Manitoba, Winnipeg, MB R3T 2N2, Canada
}

\section{ABSTRACT}

The aim of this study was to investigate whether the ruminal epithelium activates a local inflammatory response following a short-term subacute ruminal acidosis (SARA) challenge. Seven ruminally cannulated, nonpregnant, nonlactating beef heifers, fed a baseline total mixed ration (TMR) with 50:50 forage-to-concentrate ratio, were used in a crossover design with 2 periods and 2 treatments: SARA and control $(\mathrm{CON})$. Induction of SARA included feed restriction (25\% of dry matter intake [DMI] for $24 \mathrm{~h}$ ) followed by a grain overload (30\% of baseline DMI) and provision of the full TMR; whereas, the CON group received the TMR ad libitum. Ruminal $\mathrm{pH}$ was recorded using indwelling probes, and ruminal lipopolysaccharide (LPS) concentration was measured daily following the challenge until $\mathrm{d} 6$. Biopsies of ruminal papillae from the ventral sac were collected on d 2 and 6 after the grain overload. Transcript abundance of genes associated with acute inflammation was measured by quantitative real-time PCR, normalized to the geometric mean of 3 stable housekeeping genes. Target genes included toll-like receptor-2 (TLR2), TLR4, TLR9, tumor necrosis factor- $\alpha$ (TNFA), prostaglandin endoperoxide synthase-1 (PTGS1), PTGS2 transforming growth factor $\beta-1$ (TGFB1), and 4 intermediate enzymes of leukotriene synthesis (ALOX5, ALOX5AP, LTA4H, and $L T C 4 S)$. Protein localization and expression of TLR4 were quantified by image analysis of fluorescence intensity. Statistical analysis was performed using as a crossover design with fixed effects of treatment, day, and the treatment $\times$ day interaction with the random effect of day within period. Ruminal $\mathrm{pH}$ was below 5.6 for $4.5 \mathrm{~h} / \mathrm{d}$ and below 5.8 for $6.9 \mathrm{~h} / \mathrm{d}$ in the SARA group compared with 22 and $72 \mathrm{~min} / \mathrm{d}$, respectively,

Received January 14, 2019.

Accepted April 24, 2019.

*Corresponding author: greg.penner@usask.ca for CON. Ruminal LPS concentration peaked on d 2 in SARA heifers at 51,481 endotoxin units $(\mathrm{EU}) / \mathrm{mL}$ compared with 13,331 EU/mL in CON. Following grain overload, small but statistically significant decreases in the transcriptional abundance of TLR2, TLR4, TNF, PTGS2, ALOX5, and ALOX5AP were seen in SARA versus CON heifers. A functionally relevant decrease in TLR 4 expression in SARA heifers compared with CON was confirmed by a decrease in fluorescence intensity of the corresponding protein following immunohistofluorescent staining of papillae. The study results indicate a suppression of the inflammatory response in the ruminal epithelium and suggest that the response is tightly regulated, allowing for tissue recovery and return to homeostasis following SARA.

Key words: inflammation, ruminal acidosis, ruminal epithelium

\section{INTRODUCTION}

Diets for dairy and feedlot cattle often consist of a large proportion of highly fermentable carbohydrates to meet the animal's energy requirements for supporting high milk yields (Penner et al., 2009) and rates of gain (Loerch, 1990). Rapid transition to these diets can cause decreased ruminal $\mathrm{pH}$, increased osmolality of rumen fluid, and altered microbial population in the rumen (Owens et al., 1998) and lead to digestive disorders such as SARA (Bevans et al., 2005; Plaizier et al., 2008). Exposure to SARA may also reduce DMI, milk yield, and milk fat, and it has been suggested to be the causative factor for the onset of laminitis and liver abscesses (Plaizier et al., 2008; Wiese et al., 2017). Thus, SARA in cattle has important economic implications (Stone, 2004). Studies examining the effects of SARA on the host have demonstrated increased permeability of the ruminal epithelium when exposed to low pH (Aschenbach and Gabel, 2000; Penner et al., 2010) that could increase the risk for translocation of microbial-associated molecular patterns (MAMP), or 
the microbes themselves, across the epithelium, inducing a systemic acute phase protein response (Gozho et al., 2005; Khafipour et al., 2009; Humer et al., 2018).

Moreover, a local inflammatory response by the ruminal epithelium has been hypothesized (Humer et al., 2018) as a consequence of exposure to MAMP, such as LPS. The limited support for this hypothesis comes primarily in the form of studies reporting the expression of genes associated with antigen recognition (Malmuthuge et al., 2012) and inflammation (Zhang et al., 2016). These studies demonstrated an upregulation of immune-associated genes in whole ruminal papillae from cows fed a high-concentrate diet, thereby suggesting a local inflammatory response. However, due to the use of whole ruminal tissue, other cell types, such as tissue resident leukocytes, could be confounding the results. As such, the evidence to support a direct role of the ruminal epithelium in initiating a local inflammatory response is lacking. The objective of the current study was to investigate gene expression and protein localization associated with a local inflammatory response in the ruminal epithelium following a moderate, 1-d SARA challenge.

\section{MATERIALS AND METHODS}

All experimental procedures involving the use of heifers were pre-approved by the University of Saskatchewan Animal Research Ethics Board (protocol no. 20100021) and were conducted in accordance with guidelines set forth by the Canadian Council of Animal Care (Ottawa, ON, Canada).

\section{Experimental Design}

Seven nonpregnant, nonlactating crossbred beef heifers that were previously fit with a ruminal cannula were selected based on similarity and availability and used in a crossover design study. The heifers had an average body weight of $720 \mathrm{~kg} \pm 67 \mathrm{SD}$. The study design included 2 treatments and 2 periods lasting $8 \mathrm{~d}$ each with a 28 -d recovery phase between the 2 periods. The heifers were housed in individual tie-stalls with rubber mats on the floor and chopped straw used for bedding. Feed mangers were completely separated by concrete dividers to facilitate measurement of individual intakes, and water was offered free-choice. For $14 \mathrm{~d}$ before the experiment, at $0900 \mathrm{~h}$, heifers were fed a total mixed ration $(31.7 \%$ barley silage, $17.6 \%$ alfalfa hay, $23.4 \%$ barley grain, $1.8 \%$ canola meal, $24.2 \%$ of a pellet that contained $45.2 \%$ ground barley grain, $17.3 \%$ ground corn grain, $7.5 \%$ pea grain, $7.5 \%$ canola meal, $8.3 \%$ soybean meal, $2 \%$ corn gluten meal, $3.3 \%$ corn distillers medium spirits, $2.7 \%$ premix, 1.5\% Energy Booster 100 (Milk
Specialties Global, Eden Prairie, MN), 1.2\% molasses, $0.08 \%$ biotin, $0.5 \%$ ReShure choline (Balchem, New Hampton, NY), $0.04 \%$ niacin, $0.2 \%$ potassium magnesium sulfate, $1.1 \%$ sodium bicarbonate, $1.2 \%$ limestone, $0.02 \%$ (Novus International, St. Charles, MO), 0.5\% salt, $0.8 \%$ Jefo Dairy Fat (Jefo Nutrition Inc., SaintHyacinthe, QC, Canada), $0.2 \%$ limestone, $0.2 \%$ sodium bicarbonate, and 0.2\% Metasmart (Adisseo, Shanghai, China), on a DM basis, ad libitum, to allow for environmental and dietary adaptation. Subsequently, heifers were randomly assigned to 1 of 2 treatment sequences. The treatments consisted of either a control (CON) or a SARA induction treatment. Subacute ruminal acidosis was induced by restricting feed to $25 \%$ of DMI for $24 \mathrm{~h}$ followed by a grain overload (30\% of DMI with pelleted barley; adapted from Dohme et al., 2008 and Schwaiger et al., 2013a). The full allocation of each heifer's TMR was provided $2 \mathrm{~h}$ after the grain overload. The CON heifers received the TMR ad libitum.

\section{Data and Sample Collection}

DMI and Ruminal $p H$. The amounts of feed offered and feed refused were recorded throughout the study. Dry matter intake was estimated based on the DM of the TMR offered and refused. Although DMI was determined daily, DMI data from d 0 to 6 , relative to the grain overload, were used for data analysis.

Ruminal $\mathrm{pH}$ was measured for 6 consecutive days starting on the day of the grain challenge using an indwelling pH measurement system (Dascor, Escondido, CA; Penner et al., 2006). Before and after placement, the $\mathrm{pH}$ systems were standardized in $\mathrm{pH}$ buffers 7.0 and 4.0 at $39^{\circ} \mathrm{C}$. Placement of the $\mathrm{pH}$ systems in the ventral sac of the rumen was maintained using two 900$\mathrm{g}$ weights attached to a shroud around the electrode to ensure the electrode remained in the ventral sac of the rumen (Penner et al., 2006). The systems were removed and data were downloaded on d 6 after the grain overload. The data were converted from millivolts to $\mathrm{pH}$ using the linear relationship established with the pre- and post-standardization readings, and a linear drift over time was assumed. Maximum, mean, and minimum $\mathrm{pH}$, as well as the duration (min) and area $(\min \times \mathrm{pH})$ that $\mathrm{pH}$ was $<5.8$ and $<5.6$, were calculated for each 24 -h interval for d 0 to $\mathrm{d} 5$ relative to the grain overload. As ruminal digesta were removed to facilitate collection of ruminal biopsies, ruminal $\mathrm{pH}$ data from the start of the digesta evacuation procedure and that occurring until 1 $\mathrm{h}$ following reintroduction of the digesta were removed from the data set.

Ruminal Fluid Collection and Preparation. Ruminal fluid samples were collected at $1300 \mathrm{~h}$ on the day of the ruminal acidosis induction ( $\mathrm{d} 0$ of each 
sampling period) and on d 1 to 6 . Equal volumes of mixed digesta $(250 \mathrm{~mL})$ were collected from 3 locations in the rumen (cranial, central-ventral, and caudal sacs). Digesta were pooled and then strained through 2 layers of cheesecloth. The resulting ruminal fluid was mixed well and collected in conical centrifuge tubes (Corning Inc., Corning, NY). Ruminal fluid was immediately placed on ice and used for free LPS analysis as described by Khafipour et al. (2009). Briefly, the ruminal fluid samples were centrifuged at $10,000 \times g$ for $45 \mathrm{~min}$ at $4^{\circ} \mathrm{C}$ and subsequently filtered through a $0.2-\mu \mathrm{m}$ sterile syringe filters (Thermo Fisher Scientific, Waltham, MA) into sterile pyrogen-free glass vials with screw caps (Thermo Fisher Scientific). Filtered samples were heated to $100^{\circ} \mathrm{C}$ for $30 \mathrm{~min}$. After cooling for 10 min, samples were transferred into pyrogen-free $2-\mathrm{mL}$ microcentrifuge tubes (Thermo Fisher Scientific) and stored at $-20^{\circ} \mathrm{C}$ until being analyzed for LPS concentration.

Rumen Papillae Biopsies. Timing of the first papillae biopsy ( $\mathrm{d} 2$ following the ruminal acidosis induction) was based on previous work (Gozho et al., 2005) that showed elevated ruminal LPS, corresponding to ruminal $\mathrm{pH}$ below 5.6 on $\mathrm{d} 2$ following the addition of barley pellets to induce SARA and that short-chain fatty acid absorption was reduced on $\mathrm{d} 2$ following a similar acidosis induction model (Schwaiger et al., 2013a,b). A second biopsy was collected on d 6 following SARA induction to investigate whether an effect on gene expression would be detectable in the longer term.

On d 2 and 6 of each sample collection period, ruminal contents from each heifer were partially evacuated through the ruminal cannula and placed in a clean insulated plastic container to access ruminal papillae from the ventral sac. The ventral sac (ventral to the left longitudinal pillar) was partially externalized and approximately 30 papillae were excised using sterile surgical scissors and forceps. Ruminal papillae were immediately rinsed in ice-cold PBS and snap-frozen in liquid nitrogen. Frozen samples were stored at $-80^{\circ} \mathrm{C}$ until analysis. In addition, approximately 5 papillae were placed in embedding cassettes and fixed in $10 \%$ formalin ( $10 \%$ formaldehyde, vol/vol, in neutral phosphate buffer; Thermo Fisher Scientific).

\section{Sample Analyses}

Free Ruminal LPS. Ruminal fluid samples were analyzed for ruminal LPS concentration [endotoxin units $(\mathbf{E U}) / \mathrm{mL}$ ] using a Limulus amebocyte lysate assay, relative to a known reference endotoxin (Gozho et al., 2005).

RNA Isolation, Primer Design, and Quantitative Real-Time PCR. Frozen ruminal papillae were ground under liquid nitrogen using a mortar and pestle, and total RNA was isolated from approximately 100 mg of ground tissue using a phenol-chloroform extraction and double precipitation to remove contaminants (modified TRIzol protocol, Thermo Fisher Scientific). The RNA was treated with DNase (TURBO DNA-free Kit; Thermo Fisher Scientific), and the quantity of RNA was determined using a NanoDrop spectrophotometer ND-1000 (Thermo Fisher Scientific). The RNA integrity was subsequently assessed on a $1.2 \%$ (wt/ vol) denaturing agarose gel, on which all samples were confirmed to have clear $28 \mathrm{~S}$ and $18 \mathrm{~S}$ ribosomal RNA banding patterns. Reverse transcription was carried out with the High Capacity cDNA Reverse Transcription Kit (Thermo Fisher Scientific) following the manufacturer's instructions. The resulting cDNA was diluted with nuclease-free water to a final concentration of 10 $\mathrm{ng} / \mu \mathrm{L}$.

Target immune-related genes were selected based on the hypothesized effects of high LPS concentrations in the rumen. Primers for prostaglandin-endoperoxidase synthase 1 and 2 (PTGS1 and PTGS2), arachidonate 5-lipoxygenase $(A L O X 5)$, arachidonate 5-lipoxygenaseactivating protein $(A L O X 5 A P)$, leukotriene A4 hydrolase $(L T A 4 H)$, leukotriene C4 synthase $(L T C 4 S)$, tumor necrosis factor- $\alpha(T N F)$, Toll-like receptor-2 (TLR2), TLR4, TLR9, transforming growth factor $\beta-1$ (TGFB1), and 3 housekeeping genes (ACTB, GAPDH, and $H P R T$ ) were designed using Primer3 software (Untergasser et al., 2007) based on refseq sequence data from National Center for Biotechnology Information (Bethesda, MD). When possible, primers were designed to span exon-exon junctions as identified by BLAT search against UMD 3.1 and BLAST used to verify target specificity. Primer efficiencies were verified for each primer set using a serial dilution of pooled samples (primer information is presented in Table 1). Quantitative real-time PCR was performed using 20 ng of cDNA and was run in duplicate using SsoFast EvaGreen Supermix (Bio-Rad, Hercules, CA) as per manufacturer's instructions in the CFX96 Touch RealTime PCR Detection System (Bio-Rad). The stability of housekeeping gene expression over treatment and day was verified, and the geometric mean of all 3 was subsequently used to normalize expression of all genes of interest. Expression data are presented as the $2^{-\Delta \Delta \mathrm{Ct}}$ form, with treatment held relative to the lowest average biopsy day group.

Immunohistofluorescence. To analyze slides simultaneously, we randomly selected a subset of samples from the d 2 biopsy for quantification of TLR4 expression in SARA $(\mathrm{n}=3)$ and CON $(\mathrm{n}=4)$ heifers. This approach reduced the number of experimental units, while still allowing for the control of technical variation 


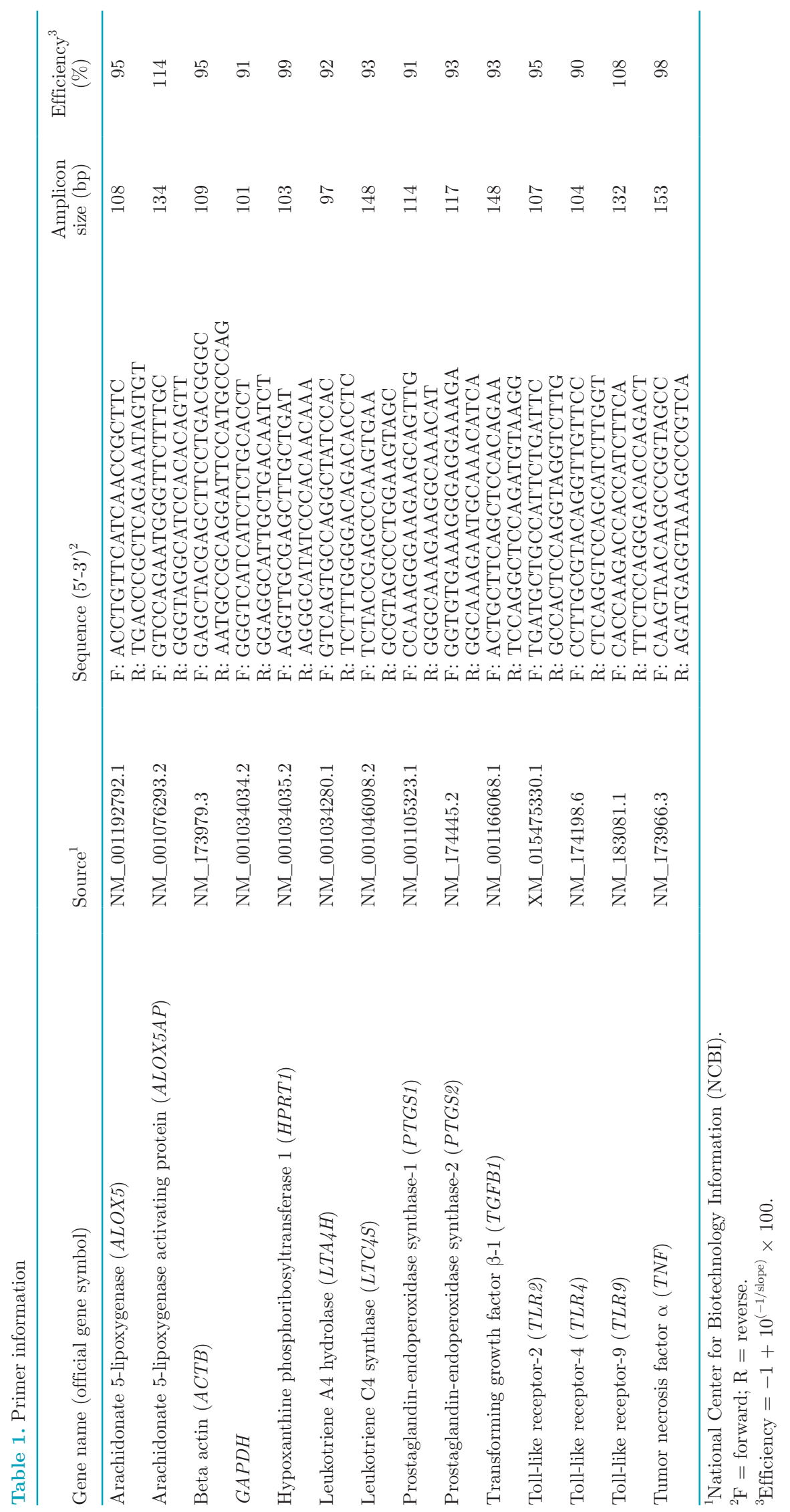


in the staining procedure and enabling the detection of large differences. All slides were processed and imaged concurrently to ensure the same conditions (e.g., incubation times, light exposure).

Tissue processing was performed at Prairie Diagnostic Services (Saskatoon, SK). In brief, tissue was dehydrated in increasing concentrations of ethanol and finally washed in xylene. Subsequently, tissue was embedded in paraffin and cut into $4-\mu \mathrm{m}$ sections that were mounted onto glass slides. The slides were then baked at $60^{\circ} \mathrm{C}$ for $20 \mathrm{~min}$, deparaffinized in xylene (Sigma-Aldrich, St. Louis, MO), and rehydrated with distilled water using a series of solutions with decreasing concentrations of ethanol. Samples were subjected to heat-induced antigen retrieval for $30 \mathrm{~min}$ at $90^{\circ} \mathrm{C}$ in Tris-EDTA buffer (10 $\mathrm{m} M$ Tris, $1 \mathrm{~m} M$ EDTA, $0.05 \%$ Tween 20, pH 9.0; Sigma-Aldrich). Slides were blocked with fetal bovine serum (Thermo Fisher Scientific) for $2 \mathrm{~h}$ at room temperature, which was followed by incubation with the primary antibody (rabbit anti-TLR4, $1 \mathrm{mg} / \mathrm{mL}$; Thermo Fisher Scientific) in a 1:250 dilution in incubation buffer (1\% BSA, 1\% horse serum, $0.3 \%$ Triton X-100, $0.01 \%$ sodium azide in PBS; SigmaAldrich) overnight at $4^{\circ} \mathrm{C}$. Isotype control slides were previously used to verify the absence of nonspecific binding. The isotype control antibody matched the primary antibody in species and concentration. Slides were washed 3 times in Tris-buffered saline $(20 \mathrm{mM}$ Tris, $150 \mathrm{mM} \mathrm{NaCl}, 0.1 \%$ Tween 20; Sigma-Aldrich), incubated with the secondary antibody at a 1:500 dilution (antirabbit Al555, $2 \mathrm{mg} / \mathrm{mL}$; Abcam, Cambridge, $\mathrm{UK}$ ) for $2 \mathrm{~h}$ at room temperature, washed again, and counterstained with 4',6-diamidino-2-phenylindole (DAPI) in methanol (Thermo Fisher Scientific). Slides were washed again and then coverslipped with Mowiol mounting medium (Sigma-Aldrich). Slides were imaged at $\times 63$ magnification using an Axiovert 200M fluorescent microscope (Zeiss, Oberkochen, Germany).

To quantify TLR4, images were analyzed using ImageJ $(1.49 \mathrm{v}$, National Institutes of Health, Bethesda, $\mathrm{MD})$. Images were captured from the base, middle, and tip of each papillae from 2 to 3 papillae per heifer for use in measuring tissue fluorescence associated with TLR4 and DAPI. Separate measurements were acquired for the stratum basale (SB), stratum spinosum and stratum granulosum combined (SS/SG), and the stratum corneum (SC) based on the morphology described by (Graham and Simmons, 2005). The procedure for measuring fluorescence intensity was adapted from McCloy et al. (2014). Mean fluorescence intensity was measured within predrawn regions of interest (ROI; selections in which the measurements are recorded) for TLR4 and DAPI as separate images (i.e., split channels). For every image, 2 ROI without fluorescence, adjacent to the tissue, were measured as background readings. The corrected total cellular fluorescence $(\mathbf{C T C F})=$ integrated density - (area of ROI $\times$ mean fluorescence of the background readings) was calculated. In addition, to quantifying total fluorescence of TLR4 and DAPI, the number of nuclei within each ROI was recorded manually (in DAPI images only). Data are presented as number of nuclei per square millimeter.

\section{Statistical Analysis}

Statistical analysis was performed using the MIXED procedure of SAS 9.4 (SAS Institute, Inc., Cary, NC). Treatment, day of biopsy, and the treatment $x$ day of biopsy interaction were considered fixed effects, and the day of biopsy within period was considered a repeated measure. No effects of period were observed and the variable and associated interactions were subsequently removed from the model. For DMI and $\mathrm{pH}$, day was considered a repeated measure. Fluorescence intensity of TLR4 was analyzed with treatment and cell layer as fixed effects. Ruminal LPS concentrations were not normally distributed and were therefore logtransformed. Statistical analysis was performed on the transformed data; however, the means and SEM are presented as EU per milliliter. Effects were considered significant when $P<0.05$ and were considered trends when $P<0.10$.

\section{RESULTS}

Dry matter intake (Table 2) did not differ between treatments, and no treatment $\times$ day interactions on DMI were observed. However, DMI has a tendency to be less for SARA versus CON (13.1 vs. $14.2 \pm 0.36 \mathrm{~kg} / \mathrm{d}$; $P=0.06$ ). Mean and minimum ruminal $\mathrm{pH}$ were $0.3 \mathrm{pH}$ units less for SARA than CON. The SARA heifers had an average duration of 414 min below pH 5.8 and 273 min below pH 5.6 throughout the $6 \mathrm{~d}$ of measurement; whereas, the duration for CON was below 5.8 and 5.6 for an average of 72 and $22 \mathrm{~min} / \mathrm{d}$, respectively.

A treatment $\times$ day interaction $(P<0.01)$ was observed for ruminal LPS concentration (Figure 1). The concentration $(\mathrm{EU} / \mathrm{mL})$ was greater in the SARA group compared with CON on d 1,2, and d 3 following the induction of SARA. No treatment effects were detected on d $0,4,5$, or 6 .

A treatment $\times$ time interaction affected the expression of TLR2 (Figure 2A), which was less abundant for SARA on d 2 and d 6 compared with CON, with a greater difference on d 2. Transcriptional abundance of TLR4 and TNF (Figures 2B and 2D) was less in SARA than CON heifers. We observed no difference in the expression of TLR9 (Figure 2C) and no differences 

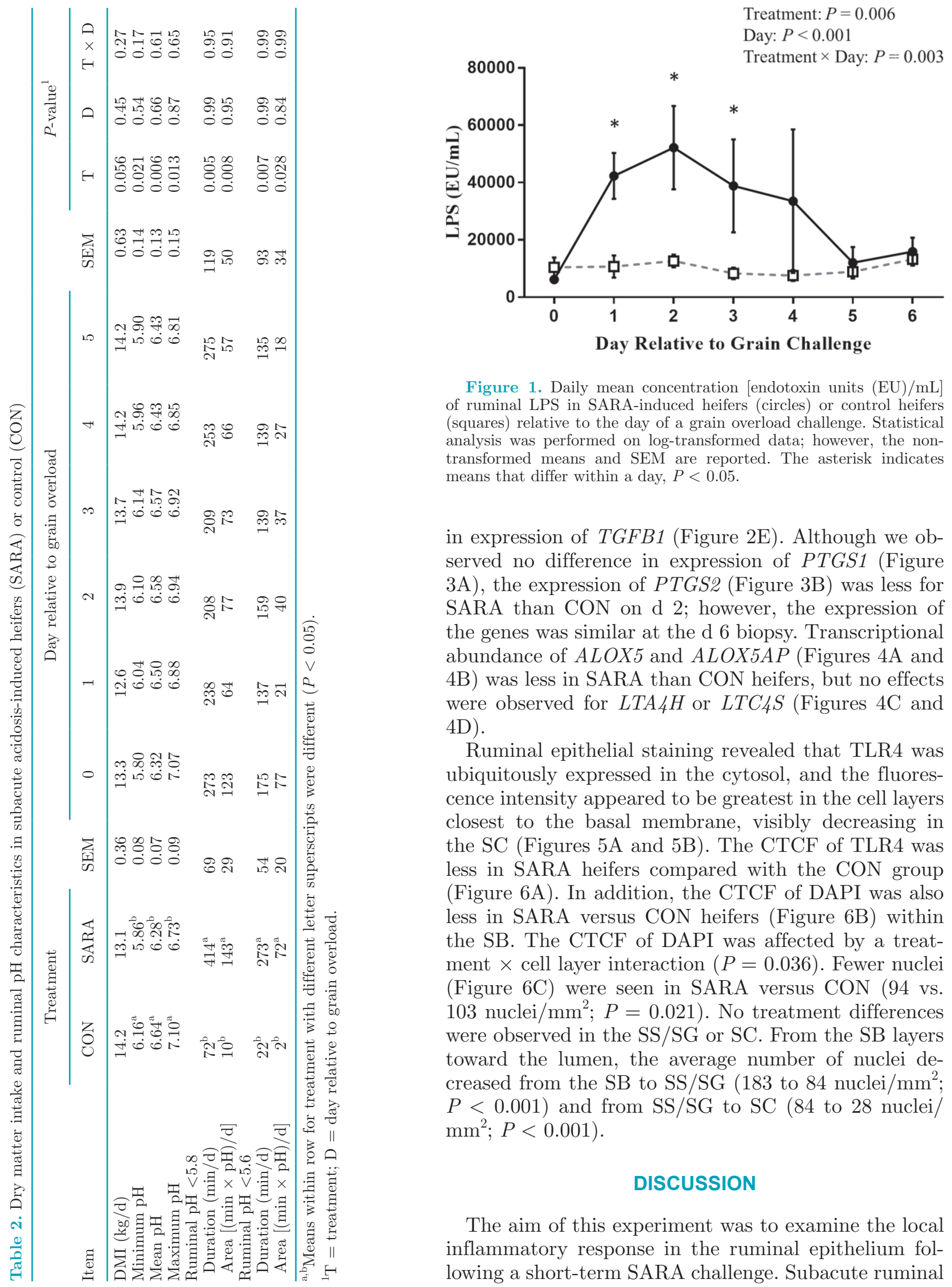

Figure 1. Daily mean concentration [endotoxin units $(\mathrm{EU}) / \mathrm{mL}$ ] of ruminal LPS in SARA-induced heifers (circles) or control heifers (squares) relative to the day of a grain overload challenge. Statistical analysis was performed on log-transformed data; however, the nontransformed means and SEM are reported. The asterisk indicates means that differ within a day, $P<0.05$.

in expression of TGFB1 (Figure 2E). Although we observed no difference in expression of PTGS1 (Figure $3 \mathrm{~A}$ ), the expression of PTGS2 (Figure 3B) was less for SARA than CON on $\mathrm{d} 2$; however, the expression of the genes was similar at the $\mathrm{d} 6$ biopsy. Transcriptional abundance of $A L O X 5$ and $A L O X 5 A P$ (Figures $4 \mathrm{~A}$ and $4 \mathrm{~B})$ was less in SARA than CON heifers, but no effects were observed for $L T A 4 H$ or $L T C 4 S$ (Figures $4 \mathrm{C}$ and 4D).

Ruminal epithelial staining revealed that TLR4 was ubiquitously expressed in the cytosol, and the fluorescence intensity appeared to be greatest in the cell layers closest to the basal membrane, visibly decreasing in the SC (Figures 5A and 5B). The CTCF of TLR4 was less in SARA heifers compared with the CON group (Figure 6A). In addition, the CTCF of DAPI was also less in SARA versus CON heifers (Figure 6B) within the SB. The CTCF of DAPI was affected by a treatment $\times$ cell layer interaction $(P=0.036)$. Fewer nuclei (Figure $6 \mathrm{C}$ ) were seen in SARA versus CON (94 vs. 103 nuclei $\left./ \mathrm{mm}^{2} ; P=0.021\right)$. No treatment differences were observed in the SS/SG or SC. From the SB layers toward the lumen, the average number of nuclei decreased from the SB to SS/SG (183 to 84 nuclei $/ \mathrm{mm}^{2}$; $P<0.001$ ) and from SS/SG to SC (84 to 28 nuclei/ $\left.\mathrm{mm}^{2} ; P<0.001\right)$.

\section{DISCUSSION}

The aim of this experiment was to examine the local inflammatory response in the ruminal epithelium following a short-term SARA challenge. Subacute ruminal 


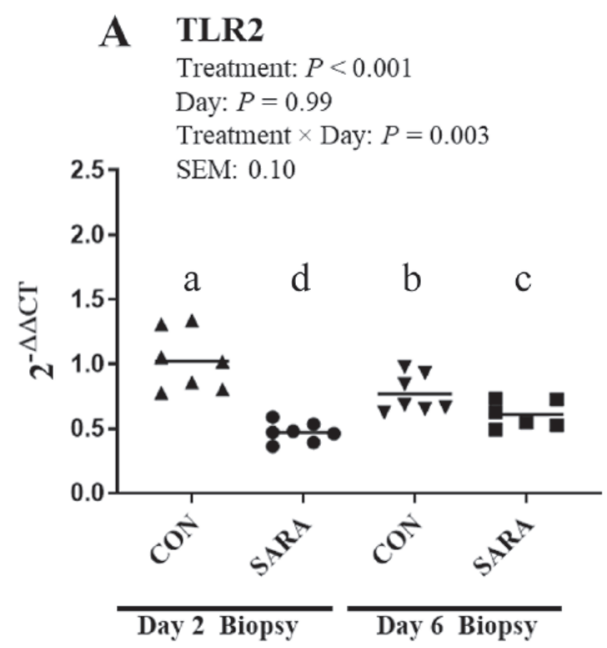

\section{TLR9}

Treatment: $P=0.23$

Day: $P=0.25$

Treatment $\times$ Day: $P=0.12$

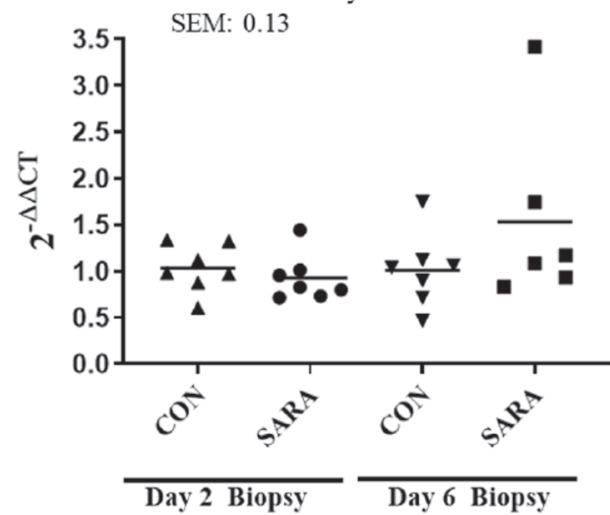

E TGFB1

Treatment: $P=0.10$

Day: $P=0.24$

Treatment $\times$ Day: $P=0.23$

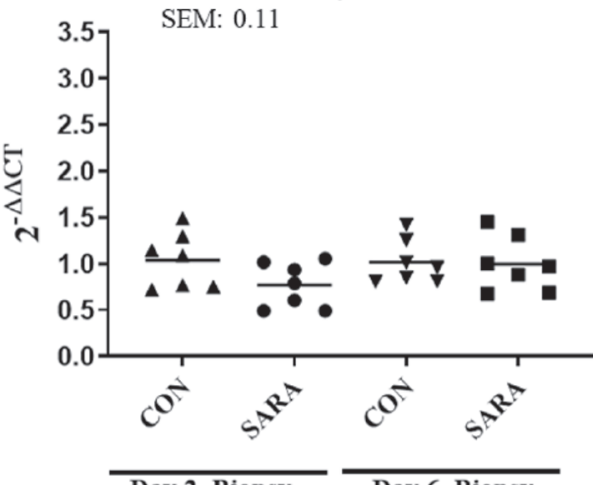

\section{B TLR4}

Treatment: $P=0.014$

Day: $P=0.91$

Treatment $\times$ Day: $P=0.06$

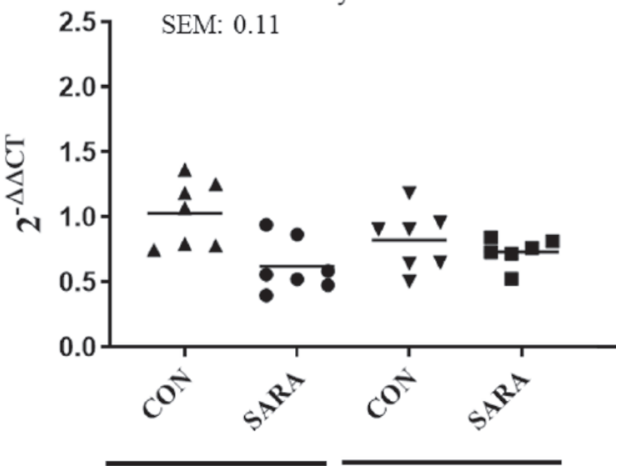

$\overline{\text { Day } 2 \text { Biopsy }}$ Day 6 Biopsy

D TNFA

Treatment: $P=0.004$

Day: $P=0.96$

Treatment $\times$ Day: $P=0.09$

3.
3.
2.
51

SEM: 0.13

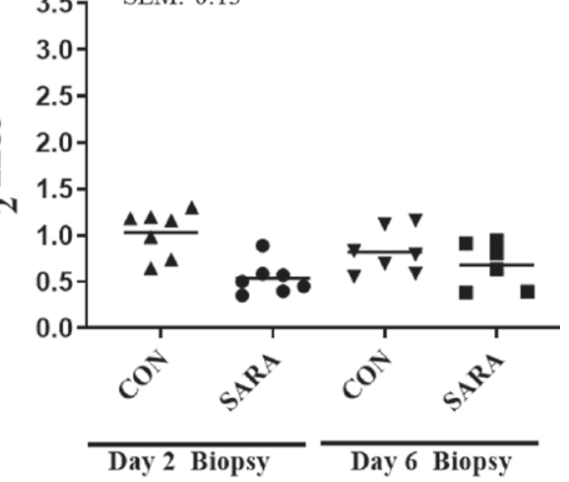

Figure 2. Expression of toll-like receptor-2 (TLR2; A), toll-like receptor-4 ( TLR 4; B), toll-like receptor-9 (TLR9; C), tumor necrosis factor- $\alpha$ (TNFA; D), and transforming growth factor $\beta-1$ (TGFB1; E) in RNA extracted from ruminal papillae. Means are compared with the treatment group within biopsy day and analyzed using quantitative real-time PCR. Values are expressed as means of fold-change relative to the baseline measurement, which was the lowest average expression. Means with different letters differ $(P<0.05)$. CON $=$ control. 

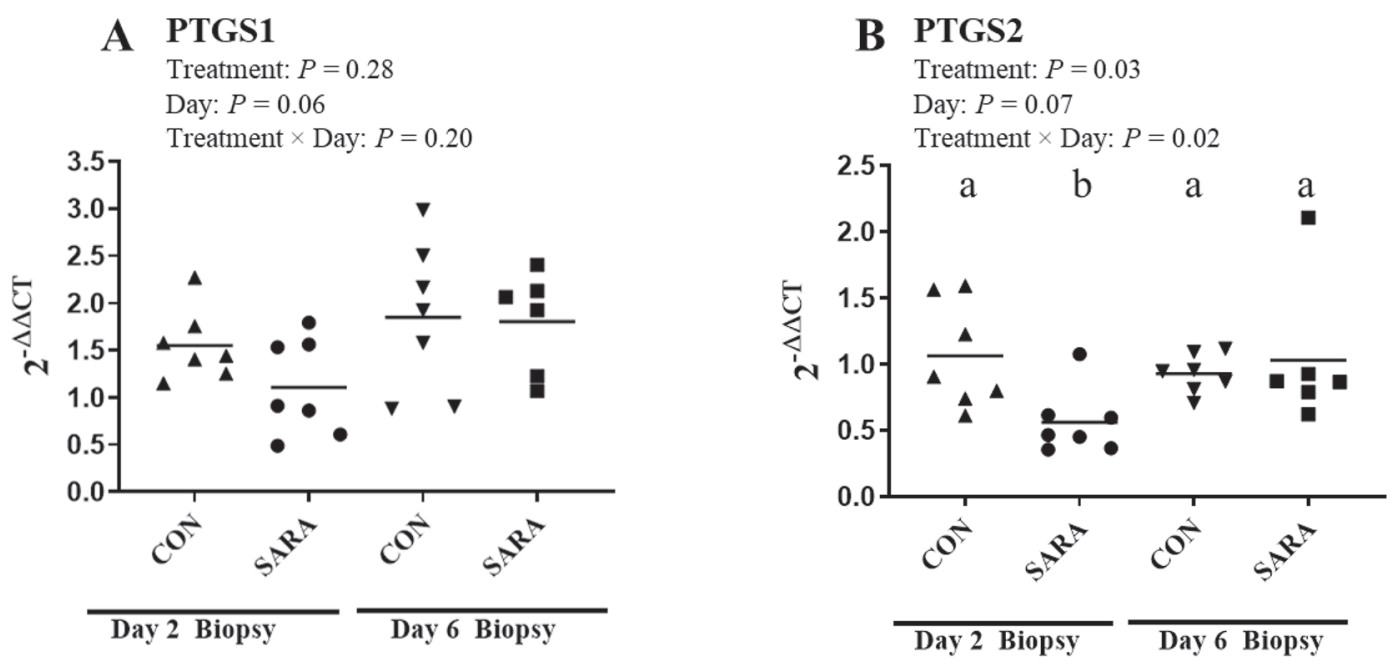

Figure 3. Expression of prostaglandin-endoperoxidase synthase-1 and -2 (PTGS1 and PTGS2; A and B, respectively) in RNA extracted from rumen papillae comparing treatment group within biopsy day, analyzed using quantitative real-time PCR. Values are expressed as means of fold-change relative to the baseline measurement, which was the lowest average expression. Means with different letters $(a, b)$ differ $(P<$ $0.05)$. $\mathrm{CON}=$ control.

acidosis has previously been defined as $\mathrm{pH}$ falling below a threshold ranging from 5.2 to 5.8 for an extended period of time (Cooper et al., 1999; Kleen et al., 2003; AlZahal et al., 2007; Penner et al., 2007). Deleterious effects of SARA, such as the induction of a systemic immune response (Humer et al., 2018), are often observed with a ruminal $\mathrm{pH}<5.6$ for at least $3 \mathrm{~h} / \mathrm{d}$ (Plaizier et al., 2008; Khafipour et al., 2009). In the current study, ruminal $\mathrm{pH}$ was below 5.8 and 5.6 for a mean duration of almost 7 and $5 \mathrm{~h} / \mathrm{d}$, respectively, following induction of acidosis. However, only a small decline in mean ruminal $\mathrm{pH}$ was observed, therefore induction of moderate SARA was considered successful.

In addition to low ruminal $\mathrm{pH}$, elevated ruminal LPS is thought to play an important role in proinflammatory effects in the ruminal epithelium as a consequence of increased permeability and translocation of ruminal antigens (Khafipour et al., 2009; Dong et al., 2011). Following induction of SARA, the increase in LPS concentration is highly variable. In lactating dairy cows, peak levels of LPS were reported at 151,985 EU/mL compared with 29,492 EU/mL in controls (Khafipour et al., 2009). In Jersey steers, ruminal LPS concentration increased from $3,715 \mathrm{EU} / \mathrm{mL}$ to a peak of 12,589 $\mathrm{EU} / \mathrm{mL}$ following induction of SARA (Gozho et al., 2005). In addition, caution must be observed when comparing absolute LPS concentrations in different studies because the Limulus amebocyte lysate assay used to measure LPS is highly sensitive to sampling and assay conditions (Chen and Mozier, 2013). Despite the variability, an increase from baseline in LPS concentrations in ruminal fluid indicates a disruption of the ruminal environment. Consistent with the previous reports, the present study observed that ruminal LPS concentrations increased following SARA induction and peaked at 51,481 EU/mL, compared with average baseline concentrations of $13,331 \mathrm{EU} / \mathrm{mL}$.

Humer et al. (2018) and Plaizier et al. (2018) proposed a model wherein LPS or other MAMP may interact with specific pattern recognition receptors, such as TLR4, on the epithelium of the gastrointestinal tract to induce local inflammation. Moreover, evidence shows that following TLR activation, the ruminal epithelium is capable of inducing an inflammatory response to rumen-derived MAMP via the production of proinflammatory cytokines (Zhang et al., 2016). Direct evidence for this model is limited though. Several studies have shown that not only are TLR4 (and other TLR) expressed in ruminal epithelial tissue, but the expression may be altered by feeding a high-forage diet (Chen et al., 2012; Minuti et al., 2015; Arroyo et al., 2017; Pan et al., 2017). However, results across the literature have been inconsistent. Pan et al. (2017) reported that dairy cows fed a high-grain diet had greater transcript and protein expression of TLR4 compared with those fed a high-forage diet. In contrast, Arroyo et al. (2017) reported that of the genes tested, those associated with immune function and inflammation, including TLR4, were for the most part unchanged in the ruminal epithelium when cows were fed a rapidly fermentable diet. In the present study, expression of TLR4 and TLR2 was downregulated in the SARA group. The apparent variability in observations of $T L R$ expression in different models of acidosis may suggest that postexposure 

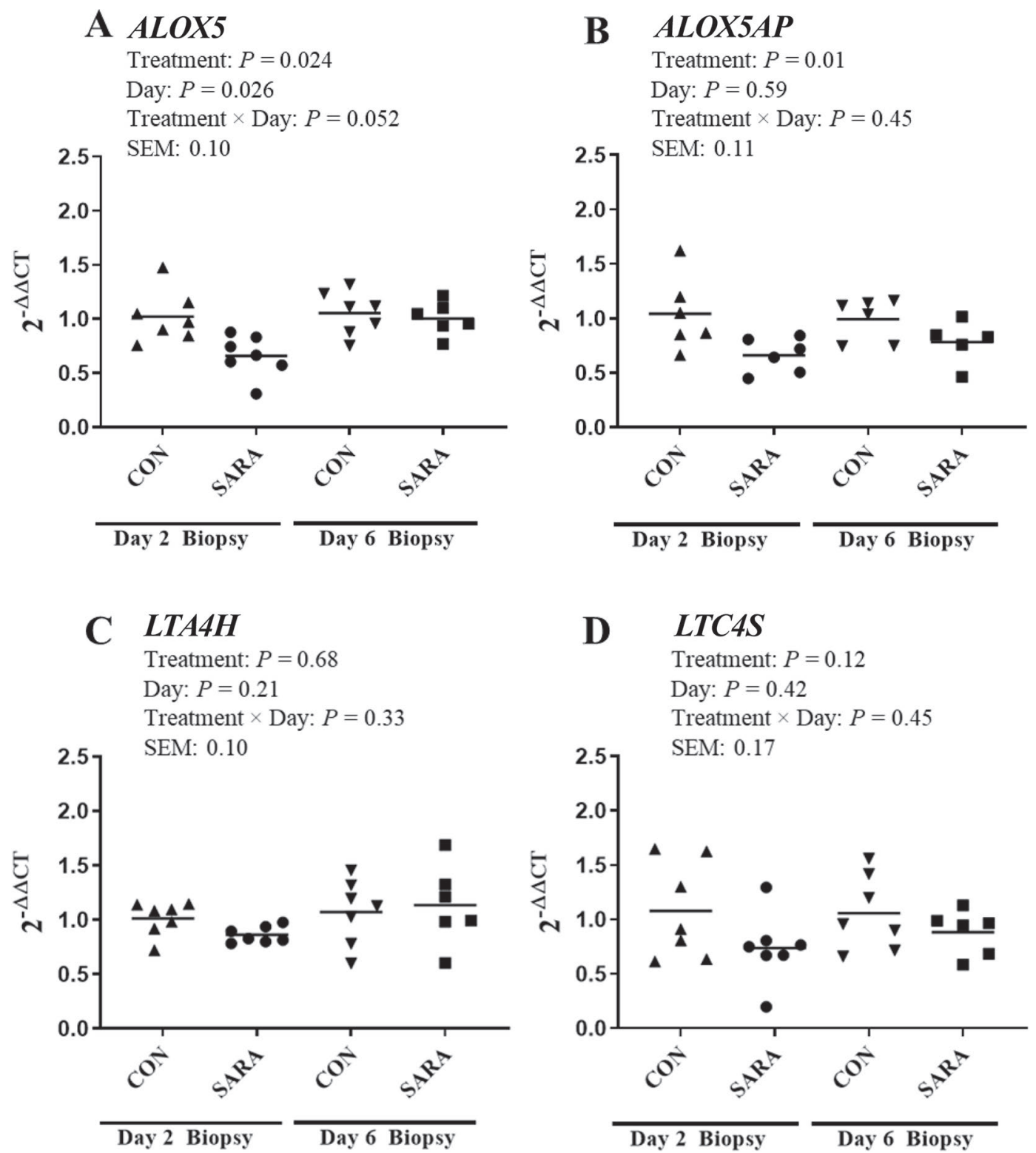

Figure 4. Expression of 4 target genes, arachidonate 5-lipoxygenase ( $A L O X 5 ; \mathrm{A})$, arachidonate 5-lipoxygenase-activating protein $(A L O X 5 A P$; $\mathrm{B})$, leukotriene A4 hydrolase (LTA $4 H ; \mathrm{C})$, and leukotriene $\mathrm{C} 4$ synthase $(L T C 4 S ; \mathrm{D})$, which are critical genes in the synthesis of leukotrienes from arachidonic acid, in RNA extracted from ruminal papillae comparing treatment group within biopsy day, analyzed using quantitative realtime PCR. Values are expressed as means of fold-change relative to the baseline measurement, which was the lowest average expression. CON $=$ control.

expression follows a complex temporal pattern that would only become apparent with more frequent tissue sampling.

In one recent study, Zhang et al. (2016) reported an increase in ruminal LPS concentration from 14,741 to $26,266 \mathrm{EU} / \mathrm{mL}$ in dairy cows following prolonged feeding of a high-grain diet. That study also demonstrated significant correlations between ruminal LPS concentration and relative mRNA expression of proinflammatory cytokines in the ruminal epithelium. Dionissopoulos et al. (2012) did not detect any differences in transcript abundance of genes associated with proinflammatory cytokines, including $T N F$, following grain-induced SARA. In contrast to previous work, the present study demonstrated a downregulation of TNF in the SARA group following a short-term grain overload. Counter regulation of proinflammatory cytokines is a key step in the initiation of the resolution phase of acute inflam- 
mation (Sugimoto et al., 2016), and the downregulation of TNF in the present study may be a result of negative feedback to effect a return to a homeostatic state.

A key step in an acute inflammatory response is the release of arachidonic acid following activation of phospholipase. Free arachidonic acid has 2 canonical fates: the cyclooxygenase (COX) pathway, responsible for the synthesis of prostaglandins, and the lipoxygenase pathway, which culminates in the production of leu- kotrienes (Medzhitov, 2008). Downstream expression of mediators of each of the distinct pathways can indicate physiological responses to stimuli such as LPS (Medzhitov, 2008).

To further investigate the apparent anti-inflammatory effect, or the suppression of a proinflammatory response, in the present study, expression of key genes associated with each of these pathways was evaluated, as well as the expression of TGFB1.
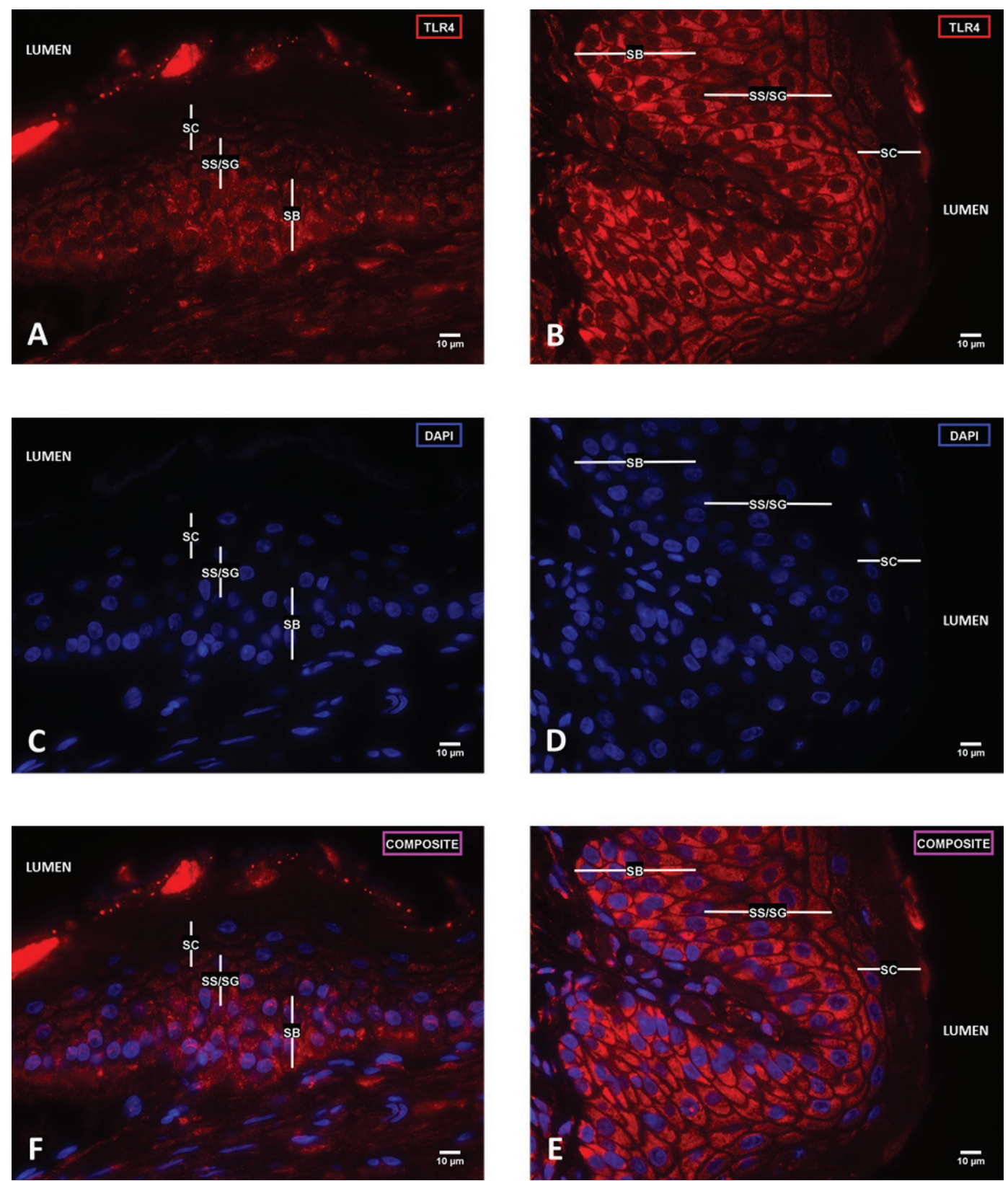

Figure 5. Staining for ruminal toll-like receptor-4 (TLR4, red) and 4',6-diamidino-2-phenylindole (DAPI, blue) in SARA-induced heifers (A and C) or controls (B and D) from the d-2 biopsy. A composite of both stainings is shown in E and F. White lines indicate the stratified epithelial cell layers: stratum basale (SB), combined stratum spinosum and granulosum (SS/SG), and stratum corneum (SC). Images are representative. 

- SARA
CON
A
TLR4
Treatment: $P=0.02$
Cell Layer: $P=0.01$
Treatment $\times$ Cell Layer: $P=0.73$
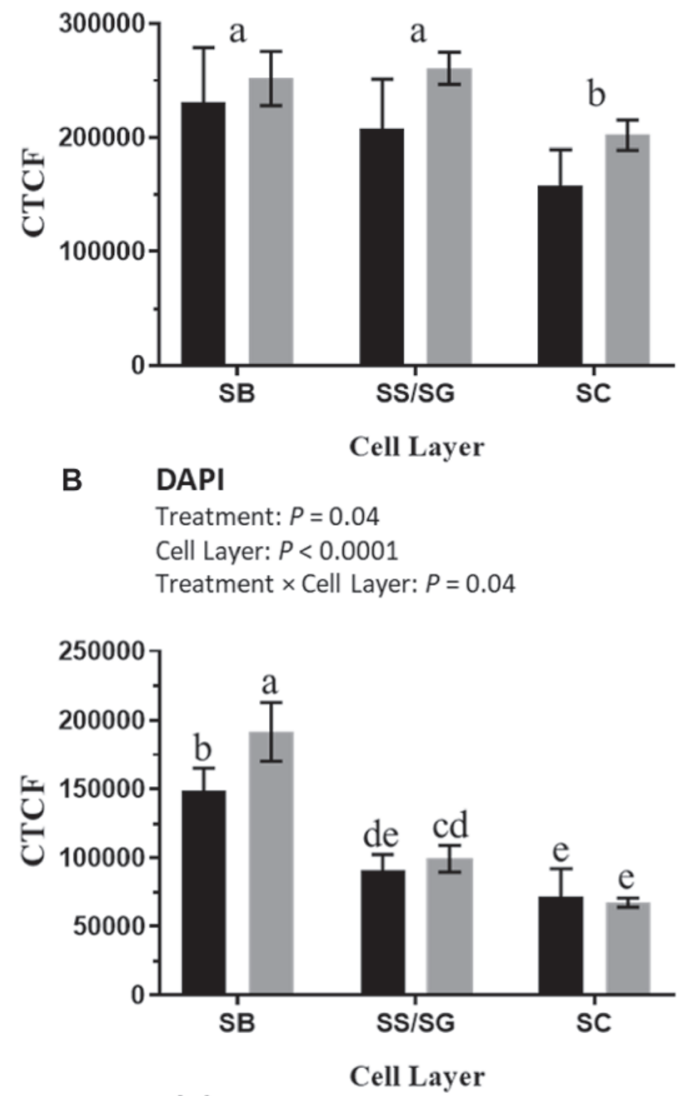

C Nuclei Count

Treatment: $P=0.03$

Cell Layer: $P<0.0001$

Treatment $\times$ Cell Layer: $P=0.15$

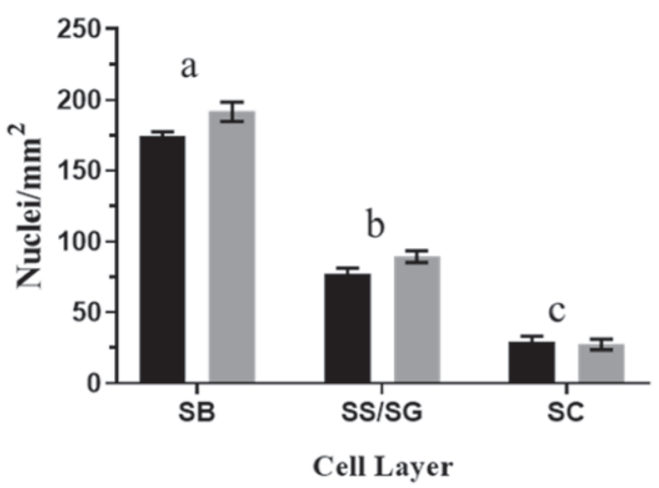

Figure 6. Corrected total cellular fluorescence (CTCF) of toll-like receptor-4 (TLR4, A) and 4',6-diamidino-2-phenylindole (DAPI, B) in SARA-induced heifers or controls $(\mathrm{CON})$ within cell layers: stratum basale (SB), combined stratum spinosum and granulosum (SS/SG), and stratum corneum (SC). Mean nuclei count (nuclei $/ \mathrm{mm}^{2}$ ) is shown in $(\mathrm{C})$. Means with different letters $(\mathrm{a}-\mathrm{e})$ differ for layer; treatment effect is denoted with $P$-value only $(P<0.05)$.
The enzymatic activity of both PTGS1 and PTGS2 (also known as COX1 and COX2) contributes to the production of prostanoids, such as prostaglandins, from arachidonic acid (Medzhitov, 2008; Ricciotti and FitzGerald, 2011). Under normal conditions, PTGS1 is constitutively expressed, while PTGS2 is responsive to stimuli and mediates a proinflammatory response (Gilroy et al., 1999; Ricciotti and FitzGerald, 2011). Previous work using knockout mouse models has shown that expression of PTGS2 is regulated by TLR4 signaling (Pasare and Medzhitov, 2005; Fukata et al., 2006). In the present study, as expected, the expression of PTGS1 did not change, whereas PTGS2 was downregulated in the SARA group compared with controls. The $T L R 4$ expression was also less in the SARA group and TLR2 expression on d 2 and $\mathrm{d} 6$ was less in the SARA group, which may partially explain the downregulation of PTGS2 in the SARA treatment.

Expression of 4 genes that regulate production of leukotrienes, ALOX5, ALOX5AP, LTA4H, and LTC4S were also analyzed. These genes are responsible for the production of molecules that have strong proinflammatory effects in response to stimuli (Rinaldo-Matthis and Haeggstrom, 2010). Expression of $A L O X 5$ and $A L-$ OX5AP in SARA heifers was downregulated compared with the CON group. Expression of TGFB1 did not differ. These results, together with those for PTGS2, TNF, TLR2, and TLR 4, provide further evidence of an initiation of the resolution phase of acute inflammation (Sugimoto et al., 2016). Expression of LTA $4 H$ and $L T C 4 S$ did not change. The reduced expression of $A L O X 5$ and $A L O X A P$ may have led to a lack of LTA 4 , upon which these enzymes act.

The inconsistencies across the literature, mentioned above, may be attributed to the common use of whole papillae or pieces of ruminal epithelium. Because ruminal papillae are composed of a heterogeneous mixture of cell types, including endothelial cells and fibroblasts that are capable of responding to MAMP, the use of this method in many studies, including the present one, results in an inability to confirm whether the ruminal epithelial cells are directly involved in the induction of a proinflammatory response. In addition, the fold changes for many genes in the present study, although statistically significant, are very small, which may be indicative of an effect at the local tissue level. It is worth noting that the targets in the present study may be altered posttranscriptionally. To confirm that the observed decrease in TLR 4 transcriptional abundance was in fact occurring in the ruminal epithelium, we quantified protein localization and abundance of the TLR4 receptor using analysis of fluorescence intensity of slides stained with a TLR4 antibody. 
Consistent with transcript abundance, analysis of fluorescence intensity indicated that TLR4 expression was less in SARA heifers compared with the CON. In addition, evidence clearly supported the intracellular localization of TLR4 within the ruminal epithelium. This finding differs from studies of monogastric small and large intestinal epithelial cells during inflammation of the epithelium that show localization of TLR4 at the apical and basolateral surfaces (Hamonic et al., 2018). The intracellular localization found in the ruminal epithelium may suggest a reduced sensitivity due to limited interactions with the MAMP ligands, such as LPS.

We also analyzed fluorescence intensity of the nuclear counterstain DAPI and found it to be less in the SARA group compared with CON in the SB cells, which suggested a potential difference in the number of cells in that strata. With further investigation, we found that the SARA group in fact had fewer SB cells. Previous work has demonstrated a nonimmune effect of TLR signaling on the cell cycle (Hasan et al., 2005). RakoffNahoum et al. (2004) demonstrated a role of TLR signaling in promoting proliferation, tissue repair, and maintaining homeostasis of intestinal epithelial cells. Neal et al. (2012) showed that TLR4 was expressed in progenitor intestinal epithelial cells and that proliferation and apoptosis could be regulated through activation of TLR4. The downregulation of TLR4 for SARA heifers in the present study may be associated with a suppression of proliferation in the SB. Leukotrienes have been previously been shown to promote intestinal epithelial cell proliferation (Paruchuri and Sjölander, 2003), and thus the decreased expression of $A L O X 5$ and $A L O X 5 A P$ may provide an alternate explanation for changes in cellular density. These findings are also consistent with the decrease in short-chain fatty acid absorption rates for cattle exposed to SARA (Schwaiger et al., 2013a,b).

In addition to the effect of SARA on TLR expression, we also investigated the localization of the receptor in the different strata of the ruminal epithelium. The average fluorescence intensity was greater in the cells closest to the basement membrane and decreased in the cells closest to the lumen. Ruminal epithelial cells lose their nuclei and differentiate into the protective keratinized SC that are in direct contact with the ruminal digesta (Graham and Simmons, 2005). Previous, albeit limited, evidence suggests a degree of tolerance in the rumen epithelium to suppress immunogenic reactions toward commensal microbes (Shen et al., 2016, 2017). Results of the current study indicate a possible tolerogenic effect in the SC that becomes an immunoreactive effect in the more basal strata, where TLR4 is highly expressed. This model also supports the concept that reduced barrier function may increase exposure of LPS to cell strata that express TLR4. Endotoxin tolerance has been previously described in ruminants (Gott, 2011; Zebeli et al., 2013), and a downregulation of TLR4 and proinflammatory cytokine expression is associated with LPS tolerance in other species and models (Nomura et al., 2000; Jiang et al., 2018). Gott et al. (2015) observed suppression of a systemic proinflammatory response following repeated exposures to LPS. The heifers used in the present study had been previously used in experiments during which they were fed high-grain diets. Despite a long adaptation period, the heifers may have developed a degree of endotoxin tolerance; however, this possibility is purely speculative and cannot be confirmed.

Another possible explanation for the pro-homeostatic response in the present study may be time of sampling. Dionissopoulos et al. (2012) suggested that inconsistencies in the expression of immune-related genes and the observed inflammatory response to a high-grain diet may be influenced by time of sampling. We speculate that the anti-inflammatory response is associated with initiation of the resolution phase of the acute inflammatory response. A probable explanation for this effect is that to prevent longer-term damage to the tissue, the acute immune response, especially the release of proinflammatory cytokines, must be tightly regulated (Buckley et al., 2001; Jura et al., 2008). This regulatory effect may be an important function of ruminal epithelial cells in maintaining tissue homeostasis (Sugimoto et al., 2016). As such, we speculate that ruminal biopsies collected closer in time to the grain overload might have revealed a proinflammatory response associated with the initial stages of inflammation, and this speculation is supported by the model in Aschenbach et al. (2019). Indeed, recent work from our laboratory (Pederzolli et al., 2018) reported an upregulation in TLR4 and TLR2 in rumen papillae of steers and lambs $24 \mathrm{~h}$ following an acidosis challenge, indicating a proinflammatory response. Future work incorporating earlier time points is needed to further investigate the effects observed in the present study.

\section{CONCLUSIONS}

In this experiment, we hypothesized that induction of acidosis would result in a proinflammatory response. However, based on ruminal papillae biopsies collected following a grain overload, analysis of gene expression and fluorescence intensity of TLR 4 indicated that inducing ruminal acidosis resulted in a downregulation of genes associated with inflammation. These data indicate a pro-homeostatic response following acidosis, an effect that may be the result of a tightly regulated 
system required to promote resolution and tissue repair following an inflammatory reaction. Expression levels of the TLR4 protein within the different strata suggest an important role of the ruminal epithelium in regulating local inflammation. Future work is necessary to confirm this hypothesis.

\section{ACKNOWLEDGMENTS}

Funding support for the project was provided by the National Sciences and Engineering Research Council (Ottawa, Ontario, Canada).

\section{REFERENCES}

AlZahal, O., E. Kebreab, J. France, and B. W. McBride. 2007. A mathematical approach to predicting biological values from ruminal pH measurements. J. Dairy Sci. 90:3777-3785. https://doi.org/ $10.3168 /$ jds.2006-534.

Arroyo, J. M., A. Hosseini, Z. Zhou, A. Alharthi, E. Trevisi, J. S. Osorio, and J. J. Loor. 2017. Reticulo-rumen mass, epithelium gene expression, and systemic biomarkers of metabolism and inflammation in Holstein dairy cows fed a high-energy diet. J. Dairy Sci. 100:9352-9360. https://doi.org/10.3168/jds.2017-12866.

Aschenbach, J. R., and G. Gabel. 2000. Effect and absorption of histamine in sheep rumen: Significance of acidotic epithelial damage. J. Anim. Sci. 78:464-470.

Aschenbach, J. R., Q. Zebeli, A. K. Patra, G. Greco, S. Amasheh, and G. B. Penner. 2019. Symposium review: The importance of the ruminal epithelial barrier for a healthy and productive cow. J. Dairy Sci. 102:1866-1882. https://doi.org/10.3168/jds.2018-15243.

Bevans, D. W., K. A. Beauchemin, K. S. Schwartzkopf-Genswein, J. J. McKinnon, and T. A. McAllister. 2005. Effect of rapid or gradual grain adaptation on subacute acidosis and feed intake by feedlot cattle. J. Anim. Sci. 83:1116-1132.

Buckley, C. D., D. Pilling, J. M. Lord, A. N. Akbar, D. Scheel-Toellner, and M. Salmon. 2001. Fibroblasts regulate the switch from acute resolving to chronic persistent inflammation. Trends Immunol. 22:199-204.

Chen, L., and N. Mozier. 2013. Comparison of Limulus amebocyte lysate test methods for endotoxin measurement in protein solutions. J. Pharm. Biomed. Anal. 80:180-185. https://doi.org/10.1016/j .jpba.2013.03.011.

Chen, Y., M. Oba, and L. L. Guan. 2012. Variation of bacterial communities and expression of Toll-like receptor genes in the rumen of steers differing in susceptibility to subacute ruminal acidosis. Vet. Microbiol. 159:451-459. https://doi.org/10.1016/j.vetmic.2012.04 .032 .

Cooper, R. J., T. J. Klopfenstein, R. A. Stock, C. T. Milton, D. W. Herold, and J. C. Parrott. 1999. Effects of imposed feed intake variation on acidosis and performance of finishing steers. J. Anim. Sci. 77:1093-1099.

Dionissopoulos, L., M. A. Steele, O. AlZahal, J. C. Plaizier, and B. W. McBride. 2012. A characterization of inflammatory and structural markers within the rumen epithelium during grain-induced ruminal acidosis in lactating dairy cattle. Am. J. Anim. Vet. Sci. 7:141-148. https://doi.org/10.7939/R30R9MH7D.

Dohme, F., T. J. DeVries, and K. A. Beauchemin. 2008. Repeated ruminal acidosis challenges in lactating dairy cows at high and low risk for developing acidosis: Ruminal pH. J. Dairy Sci. 91:35543567. https://doi.org/10.3168/jds.2008-1264.

Dong, G., S. Liu, Y. Wu, C. Lei, J. Zhou, and S. Zhang. 2011. Dietinduced bacterial immunogens in the gastrointestinal tract of dairy cows: Impacts on immunity and metabolism. Acta Vet. Scand. 53:48. https://doi.org/10.1186/1751-0147-53-48.

Fukata, M., A. Chen, A. Klepper, S. Krishnareddy, A. S. Vamadevan, L. S. Thomas, R. Xu, H. Inoue, M. Arditi, A. J. Dannenberg, and M. T. Abreu. 2006. Cox-2 is regulated by Toll-like receptor-4 (TLR4) signaling: Role in proliferation and apoptosis in the intestine. Gastroenterology 131:862-877. https://doi.org/10.1053/j gastro.2006.06.017.

Gilroy, D. W., P. R. Colville-Nash, D. Willis, J. Chivers, M. J. PaulClark, and D. A. Willoughby. 1999. Inducible cyclooxygenase may have anti-inflammatory properties. Nat. Med. 5:698-701. https:// doi.org/10.1038/9550.

Gott, P. N. 2011. Endotoxin tolerance in lactating dairy cows. MS Thesis. The Ohio State University, Wooster.

Gott, P. N., J. S. Hogan, and W. P. Weiss. 2015. Effects of various starch feeding regimens on responses of dairy cows to intramammary lipopolysaccharide infusion. J. Dairy Sci. 98:1786-1796. https://doi.org/10.3168/jds.2014-8638.

Gozho, G. N., J. C. Plaizier, D. O. Krause, A. D. Kennedy, and K. M. Wittenberg. 2005. Subacute ruminal acidosis induces ruminal lipopolysaccharide endotoxin release and triggers an inflammatory response. J. Dairy Sci. 88:1399-1403. https://doi.org/10.3168/jds .S0022-0302(05)72807-1.

Graham, C., and N. L. Simmons. 2005. Functional organization of the bovine rumen epithelium. Am. J. Physiol. Regul. Integr. Comp. Physiol. 288:R173-R181. https://doi.org/10.1152/ajpregu.00425 .2004 .

Hamonic, G., J. A. Pasternak, and H. L. Wilson. 2018. Recognizing conserved non-canonical localization patterns of toll-like receptors in tissues and across species. Cell Tissue Res. 372:1-11. https:// doi.org/10.1007/s00441-017-2767-9.

Hasan, U. A., G. Trinchieri, and J. Vlach. 2005. Toll-like receptor signaling stimulates cell cycle entry and progression in fibroblasts. J. Biol. Chem. 280:20620-20627. https://doi.org/10.1074/jbc .M500877200.

Humer, E., R. M. Petri, J. R. Aschenbach, B. J. Bradford, G. B. Penner, M. Tafaj, K.-H. Südekum, and Q. Zebeli. 2018. Invited review: Practical feeding management recommendations to mitigate risk for subacute ruminal acidosis in dairy cattle. J. Dairy Sci. 101:872-888. https://doi.org/10.3168/jds.2017-13191.

Jiang, K., S. Guo, T. Zhang, Y. Yang, G. Zhao, A. Shaukat, H. Wu, and G. Deng. 2018. Downregulation of TLR4 by miR-181a provides negative feedback regulation to lipopolysaccharide-induced inflammation. Front. Pharmacol. 9:142. https://doi.org/10.3389/ fphar.2018.00142.

Jura, J., P. Wegrzyn, M. Korostynski, K. Guzik, M. OczkoWojciechowska, M. Jarzab, M. Kowalska, M. Piechota, R. Przewlocki, and A. Koj. 2008. Identification of interleukin-1 and interleukin-6-responsive genes in human monocyte-derived macrophages using microarrays. Biochim. Biophys. Acta 1779:383-389. https://doi.org/10.1016/j.bbagrm.2008.04.006.

Khafipour, E., D. O. Krause, and J. C. Plaizier. 2009. A grain-based subacute ruminal acidosis challenge causes translocation of lipopolysaccharide and triggers inflammation. J. Dairy Sci. 92:10601070. https://doi.org/10.3168/jds.2008-1389.

Kleen, J. L., G. A. Hooijer, J. Rehage, and J. P. Noordhuizen. 2003. Subacute ruminal acidosis (SARA): A review. J. Vet. Med. A Physiol. Pathol. Clin. Med. 50:406-414.

Loerch, S. C. 1990. Effects of feeding growing cattle high-concentrate diets at a restricted intake on feedlot performance. J. Anim. Sci. 68:3086-3095.

Malmuthuge, N., M. Li, P. Fries, P. J. Griebel, and L. L. Guan. 2012. Regional and age dependent changes in gene expression of Tolllike receptors and key antimicrobial defence molecules throughout the gastrointestinal tract of dairy calves. Vet. Immunol. Immunopathol. 146:18-26. https://doi.org/10.1016/j.vetimm.2012.01.010.

McCloy, R. A., S. Rogers, C. E. Caldon, T. Lorca, A. Castro, and A. Burgess. 2014. Partial inhibition of Cdk1 in G 2 phase overrides the SAC and decouples mitotic events. Cell Cycle 13:1400-1412. https://doi.org/10.4161/cc.28401.

Medzhitov, R. 2008. Origin and physiological roles of inflammation. Nature 454:428-435. https://doi.org/10.1038/nature07201.

Minuti, A., A. Palladino, M. J. Khan, S. Alqarni, A. Agrawal, F. Piccioli-Capelli, F. Hidalgo, F. C. Cardoso, E. Trevisi, and J. J. Loor. 2015. Abundance of ruminal bacteria, epithelial gene expres- 
sion, and systemic biomarkers of metabolism and inflammation are altered during the peripartal period in dairy cows. J. Dairy Sci. 98:8940-8951. https://doi.org/10.3168/jds.2015-9722.

Neal, M. D., C. P. Sodhi, H. Jia, M. Dyer, C. E. Egan, I. Yazji, M. Good, A. Afrazi, R. Marino, D. Slagle, C. Ma, M. F. Branca, T. Prindle Jr., Z. Grant, J. Ozolek, and D. J. Hackam. 2012. Toll-like receptor 4 is expressed on intestinal stem cells and regulates their proliferation and apoptosis via the p53 up-regulated modulator of apoptosis. J. Biol. Chem. 287:37296-37308. https://doi.org/10 $.1074 /$ jbc.M112.375881.

Nomura, F., S. Akashi, Y. Sakao, S. Sato, T. Kawai, M. Matsumoto, K. Nakanishi, M. Kimoto, K. Miyake, K. Takeda, and S. Akira. 2000. Cutting edge: Endotoxin tolerance in mouse peritoneal macrophages correlates with down-regulation of surface toll-like receptor 4 expression. J. Immunol. 164:3476-3479.

Owens, F. N., D. S. Secrist, W. J. Hill, and D. R. Gill. 1998. Acidosis in cattle: A review. J. Anim. Sci. 76:275-286.

Pan, L. F., L. Yu, L. M. Wang, J. T. He, J. L. Sun, X. B. Wang, Z. H. Bai, H. Wang, T. L. Yan, and H. H. Pei. 2017. The Toll-like receptor 4 antagonist TAK-242 protects against chronic pancreatitis in rats. Mol. Med. Rep. 16:3863-3868. https://doi.org/10.3892/mmr 2017.7105.

Paruchuri, S., and A. Sjölander. 2003. Leukotriene D4 mediates survival and proliferation via separate but parallel pathways in the human intestinal epithelial cell line Int 407. J. Biol. Chem. 278:45577-45585. https://doi.org/10.1074/jbc.M302881200.

Pasare, C., and R. Medzhitov. 2005. Toll-like receptors: Linking innate and adaptive immunity. Adv. Exp. Med. Biol. 560:11-18. https:// doi.org/10.1007/0-387-24180-9_2.

Pederzolli, R. A., A. G. Van Kessel, J. Campbell, S. Hendrick, K. M. Wood, and G. B. Penner. 2018. Effect of ruminal acidosis and short-term low feed intake on indicators of gastrointestinal barrier function in Holstein steers. J. Anim. Sci. 96:108-125. https://doi .org/10.1093/jas/skx049.

Penner, G. B., K. A. Beauchemin, and T. Mutsvangwa. 2006. An evaluation of the accuracy and precision of a stand-alone submersible continuous ruminal $\mathrm{pH}$ measurement system. J. Dairy Sci. 89:2132-2140. https://doi.org/10.3168/jds.S0022-0302(06)72284 -6 .

Penner, G. B., K. A. Beauchemin, and T. Mutsvangwa. 2007. Severity of ruminal acidosis in primiparous Holstein cows during the periparturient period. J. Dairy Sci. 90:365-375. https://doi.org/10 .3168/jds.S0022-0302(07)72638-3.

Penner, G. B., M. Oba, G. Gabel, and J. R. Aschenbach. 2010. A single mild episode of subacute ruminal acidosis does not affect ruminal barrier function in the short term. J. Dairy Sci. 93:48384845. https://doi.org/10.3168/jds.2010-3406.

Penner, G. B., P. Yu, and D. A. Christensen. 2009. Effect of replacing forage or concentrate with wet or dry distillers' grains on the productivity and chewing activity of dairy cattle. Anim. Feed Sci. Technol. 153:1-10. https://doi.org/10.1016/j.anifeedsci.2009.05 .006 .

Plaizier, J. C., M. Danesh Mesgaran, H. Derakhshani, H. Golder, E. Khafipour, J. L. Kleen, I. Lean, J. Loor, G. Penner, and Q. Zebeli. 2018. Review: Enhancing gastrointestinal health in dairy cows. Animal 12:s399-s418. https://doi.org/10.1017/S1751731118001921.

Plaizier, J. C., D. O. Krause, G. N. Gozho, and B. W. McBride. 2008 Subacute ruminal acidosis in dairy cows: The physiological causes, incidence and consequences. Vet. J. 176:21-31. https://doi.org/10 $.1016 /$ j.tvjl.2007.12.016.

Rakoff-Nahoum, S., J. Paglino, F. Eslami-Varzaneh, S. Edberg, and R. Medzhitov. 2004. Recognition of commensal microflora by toll-like receptors is required for intestinal homeostasis. Cell 118:229-241. https://doi.org/10.1016/j.cell.2004.07.002.

Ricciotti, E., and G. A. FitzGerald. 2011. Prostaglandins and inflammation. Arterioscler. Thromb. Vasc. Biol. 31:986-1000. https:// doi.org/10.1161/ATVBAHA.110.207449.

Rinaldo-Matthis, A., and J. Z. Haeggstrom. 2010. Structures and mechanisms of enzymes in the leukotriene cascade. Biochimie 92:676-681. https://doi.org/10.1016/j.biochi.2010.01.010.

Schwaiger, T., K. A. Beauchemin, and G. B. Penner. 2013a. The duration of time that beef cattle are fed a high-grain diet affects the recovery from a bout of ruminal acidosis: Dry matter intake and ruminal fermentation. J. Anim. Sci. 91:5729-5742. https://doi .org/10.2527/jas.2013-6471.

Schwaiger, T., K. A. Beauchemin, and G. B. Penner. 2013b. Duration of time that beef cattle are fed a high-grain diet affects the recovery from a bout of ruminal acidosis: Short-chain fatty acid and lactate absorption, saliva production, and blood metabolites. J. Anim. Sci. 91:5743-5753. https://doi.org/10.2527/jas.2013-6472.

Shen, H., Z. Lu, Z. Chen, Y. Wu, and Z. Shen. 2016. Rapid fermentable substance modulates interactions between ruminal commensals and toll-like receptors in promotion of immune tolerance of goat rumen. Front. Microbiol. 7:1812. https://doi.org/10.3389/ fmicb.2016.01812

Shen, H., Z. Lu, Z. Xu, and Z. Shen. 2017. Diet-induced reconstruction of mucosal microbiota associated with alterations of epithelium lectin expression and regulation in the maintenance of rumen homeostasis. Sci. Rep. 7:3941. https://doi.org/10.1038/s41598-017 $-03478-2$.

Stone, W. C. 2004. Nutritional approaches to minimize subacute ruminal acidosis and laminitis in dairy cattle. J. Dairy Sci. 87:E13-E26. https://doi.org/10.3168/jds.S0022-0302(04)70057-0.

Sugimoto, M. A., L. P. Sousa, V. Pinho, M. Perretti, and M. M. Teixeira. 2016. Resolution of inflammation: What controls its onset? Front. Immunol. 7:160. https://doi.org/10.3389/fimmu.2016 .00160

Untergasser, A., H. Nijveen, X. Rao, T. Bisseling, R. Geurts, and J. A. Leunissen. 2007. Primer3Plus, an enhanced web interface to Primer3. Nucleic Acids Res. 35(Web Server issue):W71-74. https: //doi.org/10.1093/nar/gkm306

Wiese, B. I., S. Hendrick, J. G. Campbell, J. J. McKinnon, K. A. Beauchemin, T. A. McAllister, and G. B. Penner. 2017. Defining risk for low reticuloruminal $\mathrm{pH}$ during the diet transition period in a commercial feedlot in western Canada. J. Anim. Sci. 95:420-435. https://doi.org/10.2527/jas.2016.0969

Zebeli, Q., D. Mansmann, S. Sivaraman, S. M. Dunn, and B. N. Ametaj. 2013. Oral challenge with increasing doses of LPS modulated the patterns of plasma metabolites and minerals in periparturient dairy cows. Innate Immun. 19:298-314. https://doi.org/10.1177/ 1753425912461287.

Zhang, R., W. Zhu, and S. Mao. 2016. High-concentrate feeding upregulates the expression of inflammation-related genes in the ruminal epithelium of dairy cattle. J. Anim. Sci. Biotechnol. 7:42. https:// doi.org/10.1186/s40104-016-0100-1. 